\title{
ANALISIS STRATEGI PEMASARAN KAIN BATIK BESUREK DI KOTA BENGKULU
}

\author{
Sri Handayani, Siti Hanila, Mimi Kurnia Nengsih \\ Program Studi Manajemen Fakultas Ekonomi Universitas Dehasen Bengkulu \\ iiehandayani27@unived.ac.id
}

\begin{abstract}
ABSTRAK
Sri Handayani, Siti Hanila, Mimi Kurnia Nengsih; Penelitian ini bertujuan untuk mengetahui strategi pemasaran untuk produk Kain Batik Besurek di kota Bengkulu. Dan strategi mana yang paling baik dalam menentukan pemasaran Kain batik Besurek di kota Bengkulu. Metode pengumpulan data yang digunakan yaitu metode studi pustaka dan kuesioner dengan menyebarkan daftar kepada responden. Sampel dalam penelitian ini adalah asumsi strategi yang efektif memaksimalkan kekuatan dan kesempatan usaha-usaha kecil dan meminimalisir kelemahan dan ancaman .

Metode Analisis yang digunakan dalam penelitian ini adalah metode analisis SWOT (Strength, Weaknesses, Opportunity, Threats). Data- data yang diperoleh dari hasil penelitian akan dianalisa kekuatan,kelemahannya, peluangnya dan ancamannya terhadap penerapan strategi pemasaran perusahaan dalam rangka meningkatkan minat pembeli kain Batik Besurek. Untuk menentukan formulasi strategi pemasaran yang akan datang, maka digunakan penggabungan formulasi strategi pemasaran yang dihubungkan melalui matriks SWOT.
\end{abstract}

\begin{abstract}
Sri Handayani, Siti Hanila, Mimi Kurnia Nengsih; This study aims to determine the marketing strategy for batik products Besurek in Bengkulu city. And which strategy is best in determining the marketing of batik cloth of Besurek in Bengkulu city. Data collection methods used are literature study method and questionnaire by distributing the list to the respondents. The sample in this study is the assumption of an effective strategy to maximize the strengths and opportunities of small businesses and to minimize weaknesses and threats.

Analysis method used in this research is SWOT analysis method (Strength, Weaknesses, Opportunity, Threats). The data obtained from the results of the study will be analyzed strength, weakness, opportunities and amcamannya to the implementation of corporate marketing strategies in order to increase interest buyers batik cloth besurek. To determine the formulation of future marketing strategies, a merger of marketing strategy formulation is linked through the SWOT matrix
\end{abstract}

Key Words: SWOT analysis method

\section{LATAR BELAKANG}

Tanggal 2 Oktober adalah hari Batik Nasional dengan ditetapkannya sebagai warisan dunia oleh UNESCO. Batik di Indonesia begitu beragam. Setiap daerah memiliki batik dengan ciri khas tersendiri. Keunikan dan kekhasannya membuat siapapun takjub dan bangga memakainya.Di hari Batik Nasional, tak dipungkiri lagi semua media menyorot dan menjadikan pembahasan utama tentang batik. Di salah satu acara di sebuah televisi swasta mengangkat tema batik.Dalam perbincangannya, disebutkan macammacam batik dari berbagai daerah yang sering disebutkan, terkecuali, batik besurek khas Bengkulu. Sungguh sangat menyedihkan sebagai orang yang dibesarkan di Bengkulu, mereka tidak begitu kenal kain batik besurek, kebanyakan masyarakat Bengkulu mengenal batik Solo, batik Cirebon, batik lasem, batik mega mendung, dan lain-lain. Bahkan untuk di Provinsi Bengkulu sendiri, batik besurek ini tidak kalah dengan batik lain. Batik besurek hanya dipakai di perkantoran dan sekolahan, itupun batik printing. Namun untuk keseharian, warga Bengkulu nyaris tidak ada yang menggunakannya.

Ada beberapa alasan mengapa Kain Batik Besurek tidak banyak dikenal oleh masyarakat luas baik nasional maupun internasional antara lain :

a. Bengkulu masih sedikit memiliki Industri Batik yang mandiri.

Di Bengkulu industri Kain Batik Besurek yang membuatan Kain Batik Besurek kurang banyak diminati, ini dikarenakan adanya keterbatasan sumber daya manusia yang handal, dan dari segi permodalan mereka susah untuk mendapatkan pinjaman modal dengan bunga yang kecil, belum lagi permasalahan promosi dan pemasaran yang belum mampu menembus tingkat nasional apalagi ketingkat internasional, sehingga hanya sedikit yang memiliki industri Kain Batik Besurek .

b. Kurang adanya dukungan dari Pemerintah 
Sebenarnya Kain Batik Besurek juga tidak kalah bagusnya dan cantiknya dengan batik daerah lain. Namun karena minimnya dukungan pemerintah, maka geliat industri batik di Bengkulu lesu. Jika saja pemerintah memberikan bantuan dana/barang kepada pengusaha batik skala kecil/rumahan, kita yakin mereka merasa sangat terbantu. Dengan adanya pembinaan dan pinjaman lunak, tentunya para pengusaha batik tak perlu lagi mengeluarkan biaya operasional yang membuat batik jadi mahal, akan tetapi mereka memiliki mesin jahit sendiri dan merekrut para penjahit yang diberi gaji. Dan para pengusaha juga bisa mengadakan pelatihan kepada kaum ibu rumah tangga untuk membatik dan merekrut mereka sebagai pengrajin batik. Tentunya ini akan membantu menekan angka pengangguran di Bengkulu dan meningkatkan produksi batik di Bengkulu.

c. Kurangnya Promosi

Pemerintah Bengkulu kurang aktif dalam mempromosikan kebudayaan kota Bengkulu yang cukup kaya. Namun, sebenarnya untuk masalah promosi, bukan hanya tugas pemerintah saja yang berpromosi, tapi adalah tugas semua masyarakat Bengkulu.Di zaman serba canggih ini sebenarnya sudah cukup banyak media promosi, namun belum dioptimalkan lebih jauh lagi. Kita bisa mempromosikan batik besurek, lewat media massa, youtube, facebook, bbm, twitter, instagram, bahkan dalam sebuah tulisan fiksi dan nonfiksi juga kita bisa promosikan batik besurek. Dengan media tersebut bisa membantu dalam promosi. Sebenarnya jika pemerintah tidak event - event ketinggalan dalam mempromosikannya, apalagi ada yang ada hubungannya dengan batik, kain batik besurek selalu ikut dalam event tersebut baik nasional maupun internasional, seperti Jakarta Fashion Week atau acara lainnya. Tidak cukup dengan menggelar event-event besar di Bengkulu saja, kalau yang menyaksikan juga warga Bengkulu.Dalam hal ini, memang Bengkulu perlu mempercantik diri, sebelum mengadakan event di Bengkulu, karena kita perlu memancing wisatawan sebelum mempromosikan batik. Jika wisatawan datang karena keindahan alamnya, otomatis mereka akan melihat sisi lain Bengkulu, yaitu budaya dan batiknya.

Pengelolaan Kain Batik Besurek dilakukan oleh pihak terkait melalui perumusan strategi dan kebijakan. Selanjutnya strategi dan kebijakan ini ditetapkan dan diimplementasikan dalam operasional kegiatannya. Penerapan strategi dan kebijakan ini tentunya akan mempengaruhi pemasaran dan pengenalan kain batik Besurek. Jika Perumusan dan kebijakan dilakukan dengan baik, maka peminat untuk mengenal dan memasarkan akan lebih banyak.

Perumusan strategi dan kebijakan memiliki kekuatan dan kelemahan. Hal ini terjadi karena ada keterbatasan seperti keterbatasan sumber daya, keterbatasan pengelolaan informasi dan keterbatasan lainnya, sehingga diperlukan suatu analisis yang cermat mengenai posisi perusahaan baik yang mengarah kedalam (Internal) maupun yang mengarah keluar (ekstrenal).

Pada penelitian ini, peneliti akan menganalisis kekuatan (strengths) dan kelemahan (Weakness) serta peluang (opportunity) dan ancaman (treats) atau analisis SWOT terhadap strategi strategi pemasaran dalam memperkenalkan atau mempromosikan dan memasarkan kain batik Besurek kepada masyarakat baik itu di tingkat nasional maupun internasional

\section{TINJAUAN LITERATUR Ruang lingkup Kain Batik}

Batik merupakan hal yang tidak asing bagi masyarakat Indonesia saat ini. Batik merupakan salah satu warisan nusantara yang unik. Keunikannya ditunjukkan dengan barbagai macam motif yang memiliki makna tersendiri.

Menurut Asti M. dan Ambar B. Arini (2011: 1) berdasarkan etimologi dan terminologinya, batik merupakan rangkaian kata mbat dan tik. Mbat dalam bahasa Jawa dapat diartikan sebagai ngembat atau melempar berkali-kali, sedangkan tik berasal dari kata titik. Jadi, membatik artinya melempar titik berkali-kali pada kain. Adapula yang mengatakan bahwa kata batik berasal dari kata amba yang berarti kain yang lebar dan kata titik. Artinya batik merupakan titik-titik yang digambar pada media kain yang lebar sedemikian sehingga menghasilkan pola-pola yang indah. Dalam Kamus Besar Bahasa Indonesia, batik memiliki arti kain bergambar yang pembuatannya secara khusus dengan menuliskan atau menerakan malam pada kain itu, kemudian pengolahannya diproses dengan cara tertentu.

Batik sudah ada sejak jaman Majapahit dan sangat populer sampai saat ini. Tidak ada yang dapat memastikan kapan batik tercipta. Namun, motif batik dapat terlihat pada artefak seperti pada candi dan patung.

Menurut Asti M. dan Ambar B. Arini (2011: 1) kesenian batik adalah kesenian gambar di atas kain untuk pakaian yang menjadi salah satu kebudayaan keluarga raja-raja Indonesia. Memang pada awalnya batik dikerjakan hanya terbatas dalam keraton, untuk pakaian raja dan keluarga, serta para pengikutnya. Batik yang masuk kalangan istana diklaim sebagai milik dalam benteng, orang lain tidak boleh 
mempergunakannya. Hal inilah yang menyebabkan kekuasaan raja serta pola tata laku masyarakat dipakai sebagai landasan penciptaan batik. Akhirnya, didapat konsepsi pengertian adanya batik klasik dan tradisional. Penentuan tingkatan klasik adalah hak prerogatif raja. Banyaknya pengikut raja yang tinggal di luar keraton, menjadikan keterampilan membuat batik meluas dan ditiru oleh masyarakat sekitar. Bahkan membatik menjadi pekerjaan wanita untuk mengisi waktu luangnya. Akibatnya batik yang semula hanya dipakai oleh keluarga keraton, menjadi pakaian rakyat. Pada awal keberadaannya, motif batik terbentuk dari simbol-simbol bermakna, yang bernuansa tradisional JawaIslami, Hinduisme, dan Budhisme. Dalam perkembangannya, batik diperkaya oleh nuansa budaya lain seperti Cina dan Eropa modern.

Menurut Herry Lisbijanto (2013: 10-12) memaparkan bahwa ada 3 jenis batik menurut teknik pembuatannya, yaitu:

a. Batik Tulis

Batik tulis dibuat secara manual menggunakan tangan dengan alat bantu canting untuk menerakan malam pada corak batik Pembuatan batik tulis membutuhkan kesabaran dan ketelatenan yang tinggi karena setiap titik dalam motif berpengaruh pada hasil akhirnya. Motif yang dihasilkan dengan cara ini tidak akan sama persis. Kerumitan ini yang menyebabkan harga batik tulis sangat mahal. Jenis batik ini dipakai raja, pembesar keraton, dan bangsawan sebagai simbol kemewahan

b. Batik Cap

Batik cap dibuat dengan menggunakan cap atau semacam stempel motif batik yang terbuat dari tembaga. Cap digunakan untuk menggantikan fungsi canting sehingga dapat mempersingkat waktu pembuatan. Motif batik cap dianggap kurang memiliki nilai seni karena semua motifnya sama persis. Harga batik cap cukup murah karena dapat dibuat secara masal.

c. Batik Lukis

Batik lukis dibuat dengan melukiskan motif menggunakan malam pada kain putih. Pembuatan motif batik lukis tidak terpaku pada pakem motif batik yang ada. Motifnya dibuat sesuai dengan keinginan pelukis. Batik lukis ini mempunyai harga yang mahal karena tergolong batik yang eksklusif dan jumlahnya terbatas.

\section{Manajemen Pemasaran}

Definisi pemasaran menurut William J. Stanton yang dikutipoleh Swastha dan Handoko (2000: 4) : Pemasaran adalah suatu sistem keseluruhan dari kegiatankegiatan usaha yang ditujukan untuk merencanakan, menentukanharga, mempromosikan, dan mendistribusikan barang dan jasa yang memuaskan kebutuhan baik kepada pembeli yang ada maupun pembeli potensial.

Pengertian pemasaran menurut Kotler (2000: 19) : "adalah proses sosial dan manajerial dimana individu dan kelompok mendapatkan kebutuhan dan keinginan mereka dengan menciptakan, menawarkan, dan menukarkan produk yang bernilai satu sama lain".

Berdasarkan definisi diatas dapat disimpulkan bahwapemasaran mempunyai arti yang lebih luas daripada penjualan, pemasaran mencakup usaha perusahaan yang ditandai dengan mengidentifikasi kebutuhan konsumen yang perlu dipuaskan, menentukan harga produk yang sesuai, menentukan cara promosidan penjualan produk tersebut. Jadi, pemasaran juga merupakan kegiatan saling berhubungan sebagai suatu system untuk menghasilkan laba. Pemasaran merupakan hal yang sangat penting bagikeberhasilan suatu perusahaan. Terdapat falsafah dalam pemasaranyang disebut sebagai konsep pemasaran. Basu Swastha dan Hani Handoko (2000: 6) mendefinisikan konsep pemasaran sebagai berikut : "Konsep pemasaran adalah sebuah falsafah bisnis yang menyatakan bahwa pemuasan kebutuhan konsumen merupakan syarat ekonomi dan sosial bagi kelangsungan hidup perusahaan"Definisi tersebut dapat disimpulkan bahwa tujuan dari konsep pemasaran adalah memberikan kepuasan terhadap keinginan dankebutuhan konsumen. Konsep pemasaran tersebut dapat dicapai dengan usaha mengenal dan merumuskan keinginan dan kebutuhan konsumen. Perusahaan dalam memenuhi keinginan dan kebutuhan konsumen harus menyusun kebijaksanaan produk, harga, promosi dan distribusi yang tepat sesuai dengan keadaan konsumen sasarannya.

Seluruh perusahaan menginginkan bahwa seluruh kegiatan yang dijalankan berjalan dengan baik, berkembang dan mendapatkan laba yang maksimal. Langkah untuk mencapai hal tersebut diperlukan pengelolaan yang baik dalam melaksanakan seluruh kegiatan pemasaran, pengelolaan dalam rangka melaksanakan kegiatan tersebut yang dikenal dengan istilah manajemen pemasaran, Philip Kotler dalam Basu Swastha (2000:4) mendefinisikan manajemen pemasaran sebagai berikut : Manajemen pemasaran adalah penganalisaan, perencanaan, pelaksanaan dan pengawasan program-program yang ditujukan untuk mengadakan pertukaran dengan maksud untuk mencapai tujuan organisasi. Hal ini sangat tergantung pada penawaran organisasi dalam memenuhi kebutuhan dan keinginan pasar tersebut serta menentukan harga, mengadakan pelayanan dandistribusi yang efektif untuk memberitahu, mendorong 
serta melayani pasar. Definisi ini menjelaskan bahwa manajemen pemasaranmerupakan suatu proses yang menyangkut analisis, perencanaan dan pelaksanaan serta pengawasan program-program yang ditujukan untuk melayani pasar sesuai dengan kebutuhan dan keinginan pasar.

\section{Strategi Pemasaran}

Menurut Assauri (2010:168), strategi pemasaran pada dasarnya adalah rencana yang menyeluruh, terpadu dan menyatu dibidang pemasaran, yang memberikan panduan tentang kegiatan yang akan djalankan untuk dapat tercapainya tujuan pemasaran suatu perusahaan.

Menurut Prawirosentono (2009:26), strategi pemasaran adalah serangkaian kebijakan pemasaran yang terpadu dan terarah yang jadi pedoman kegiatan berbagai jenjang unit pemasaran untuk mencapai target penjualan dalam wilayah pemasaran tertentu, sesuai dengan perubahan kondisi dan lingkungan usaha bisnis bersangkutan .

Jadi strategi pemasaran bisa disimpulkan bahwa pendekatan pokok yang akan digunakan oleh unit bisnis dalam mencapai sasaran yang telah ditetapkan terlebih dahulu, didalamnya tercantum keputusankeputusan pokok mengenai target pasar, penempatan produk dipasar, bauran pemasaran dan tingkat biaya pemasaran yang dilakukan (Daryanto,2013:157).

Dalam strategi pemasaran ada tiga faktor yang menyebabkan terjadinya perubahan dalam strategi pemasaran yaitu :

1. Daur hidup produk, setiap perusahaan harus melakukan strategi agar produk yang dimiliki tidak membuat konsumen jenuh. Sehingga perusahaan agar selalu berfikir untuk menciptakan produk lainya yang sama fungsinya.

2. Posisi persaingan antar perusahaan di pasar. Setiap perusahaan harus memperhatikan posisi perusahaan dalam persaingan apakah pemimpin, penantang, mengikuti atau hanya mengambil sebagian kecil dalam persaingan dipasar.

3. Situasi Ekonomi. Perusahaan yang baik adalah perusahaan yang selalu situasi ekonomi dalam pasar serta cara pandang ke masa depan, apakah perekonomian negara berada dalam kondisi makmur atau inflasi yang ada.

\section{Konsep SWOT \\ Pengertian SWOT}

Menurut Anonym, (2009:24) Analisis SWOT adalah Identifikasi berbagai faktor secara sistematik untuk merumuskan strategi sebuah perusahaan dan organisasi internal maupun eksternal. Analisa ini didasarkan pada logika yang dapat memaksimalkan kekuatan (Strenght) dan peluang (Opportunities) dan namun secara bersamaan dapat meminimalkan kelemahan ( Weaknesses) dan ancaman (Threats).

Menurut Rangkuti, (2006:18) Analisis SWOT adalah suatu identifikasi sistematis dari faktor-faktor dan strategi yang memperlihatkan perpaduan terbaik diantara mereka. Analisis ini bertolak dari asumsi bahwa strategi yang efektif memaksimalkan kekuatan dan kesempatan perusahaan dan meminimalisir kelemahan dan ancaman, pada penerapan yang akurat, asumsi sederhana ini mempunyai implikasi kuat terhadap desain dari sebuah strategi yang berhasil

Jadi dapat disimpulkan analisis SWOT adalah singkatan dari Strengths (Kekuatan ), weaknesses (kelemahan), opportunities (peluang), dan threats (ancaman), dimana SWOT ini dijadikan sebagai suatu model dalam menganalisis suatu organisasi yang berorientasi profit dan non profit dengan tujuan utama mengetahui keadaan organisasi tersebut secara lebih konperhensif.

\section{Manfaat SWOT}

Secara umum manfaat yang dapat diperoleh perusahaan dalam penggunaan tehnik SWOT adalah untuk menemukan unsur-unsur kekuatan, kelemahan, peluang, dan ancaman yang dimiliki perusahaan. Dengan mengetahui unsur-unsur tersebut maka perusahaan lebih berhati-hati dalam menyusun strategi.

\section{Keterbatasan SWOT}

Pada uraian sebelumnya, dijelaskan bahwa suatu perusahaan beroperasi dalam banyak lingkungan, dimana semua lingkungan akan mempengaruhi perusahaan. Lingkungan tersebut perlu diperhatikan pihak manajemen, karena banyak faktor yang ditimbulkan dari lingkunga, jadi dalam hal ini biasanya perusahaan memiliki keterbatasan dalam meluangkan waktunya untuk mengamati dengan cermat setiap perubahan yang terjadi.

Tanggapan pihak perusahaan terhadap perubahan lingkungan tidak selamanya jelas, sebagian tergantung pada falsafah pimpinan, kemampu labaan, hal-hal yang dipandang manajer sedang terjadi dalam lingkungan, bagaimana presepsi manajer mengenai faktor lingkungan terhadap perusahaan dan sebaliknya. Laju perubahan dalam lingkungan yang berbeda tidaklah sama, misalnya sebuah perusahaan 
mungkun berada dalam lingkungan yang menyenangkan namun dengan lingkungan sosial yang tidak bersahabat.

\section{HASIL PENELITIAN DAN PEMBAHASAN}

Sejarah awal pertumbuhan kain besurek belum diketahui secara pasti namun menurut orangorang tua tempo dulu (pemuka adat, pemuka masyarakat) Bengkulu. Penggunaan kain besurek sudah sejak lama dan terlihat selalu dipakai pada upacara-upacara adat khususnya di Kota Bengkulu. Ada kecenderungan sejarah awal perkembangan kain besurek di Bengkulu bermula sejak hijrahnya pahlawan pangeran Sentot Alibasyah dan keluarganya ke Bengkulu. Pada saat pengasingan itu keluarga Sentot Ali Basya membawa bahan dan peralatan membuat batik, yang bertujuan untuk mengisi kesibukan selama dipengasingan. Pada saat keluarga Sentot Ali Basya melakukan pekerjaan membantik, warga Bengkulu sering melihat dan memperhatikan mereka, kemudian warga Bengkulu mulai tertarik dan minta diajarkan bagaimana cara membuat batik sampai mereka mampu membuat batik sendiri. Penggunaan kain besurek pada mulanya hanya terbatas untuk upacara-upacara adat seperti dipakai untuk pengapit pengantin pria (Destar /topi khas Bengkulu) pada acara nikah,untuk acara calon pengantin putri mandi/siraman bedabung/mengikir gigi malam inaicuri, ziarah kubur dalam rangkaian upacara perkawinan, sampiran bilik pengantin, hiasan ayunan cukur bayi, penutup jenazah dan lain sebagainya

Perkembangan kain besurek di Bengkulu hingga kini demikian pesat, mendapat perhatian dari Pemerintah Daerah dan masyarakat setempat, penggunaannya pun tidak lagi terbatas pada perayaan atau upacara-upacara adat, melainkan telah digunakan untuk berbagai keperluan seperti pakaian dinas, swasta, pakaian pesta, busana muslim, pakaian harian dengan modivikasi disain motif dan modivikasi disain busana, diversivikasi produk antara lain, dompet, dasi, tas, kopiah, asesoris tempat perhiasan, tempat ticu, souvenir/cinderamata dengan beranekaragam perpaduan disain motif flora, fauna, ornamen ukiran rumah tradisional, huruf kaganga dan lain sebagainya. Keahlian yang telah didapat oleh masyarakat Bengkulu itu terus dilakukan dan dikembangkan hingga sekarang dan untuk menjaga kelestarian Kain Besurek sekarang dilakukan pembinaan oleh beberapa lembaga antara lain Departemen Industri dan Perdagangan, Departemen Pariwisata dan Departemen Pendidikan dan kebudayaan yang menjadikan kain basurek sebagai mata pelajaran disekolah.

Kerajinan membatik resmi menjadi kerajinan Kain Besurek pada saat pemerintahan Gubernur yang dijabat oleh Bapak Razie Yahya. Banyak orang menyebutnya Batik Besurek, padahal sebenarnya yang benar adalah Kain Besurek. Motif Besurek telah berkembang dan tetap dilestarikan keberadaanya. Selain sebagai seragam wajib untuk pelajar Sekolah Dasar sampai Sekolah Menengah Atas, Kain Besurek juga dijadikan seragam wajib bagi PNS di wilayah Propinsi Bengkulu sejak tahun 1990 sesuai dengan aturan yang sudah dibuat. Ini dilakukan sebagai salah satu upaya pemerintah daerah Propinsi Bengkulu dalam mengembangkan dan melestarikan kain besurek. Sampai sekarang kain besurek sudah dipakai dan dikenal semua orang dari berbagai kalangan bahkan kain besurek sudah sering ditampilkan dalam berbagai acara baik secara nasional maupun internasional.

Kesenian dan kebudayaan Bengkulu merupakan kebudayaan asli Kota Bengkulu yang memiliki ciri khas Kerajinan Tradisional yaitu Kain Besurek yang memiliki berbagai macam motif:

\section{1. motif kaligrafi}

Merupakan motif yang diambil dari huruf-huruf kaligrafi. Untuk batik besurek modern, biasanya

kaligrafinya tidak memiliki makna.

2. motif bunga rafflesia

Bergambar bunga rafflesia arnoldi yang merupakan bunga raksasa khas Bengkulu. motif bunga

rafflesia bisa dibilang sebagai motif utama kain besurek setelah kaligrafi.

3. motif burung kuau

Bergambar seperti burung, tetapi terbuat dari rangkaian huruf-huruf kaligrafi.

4. motif relung paku

Bentuknya meliuk-liuk, persis seperti tanaman relung paku.

5. motif rembulan

Merupakn motif yang digambar seperti rembulan yang bulat. Biasanya dipadukan dengan motif kaligrafi.

\section{Motif Cengkeh}

Bergambar tanaman cengkeh

Ini membuktikan bahwa tiap daerah yang ada di Indonesia memiliki budaya daerah masingmasing. Sekarang Kain Besurek sudah ditetapkan menjadi salah satu warisan budaya Indonesia dari Propinsi Bengkulu. Hal ini berdasarkan dari hasil sidang penetapan warisan Budaya tak benda Indonesia tahun 2015 dilaksanakan pada tanggal 20-23 September 2015 di Jakarta. Dalam sidang ini diputuskan 
sebanyak 121 karya budaya untuk ditetapkan sebagai warisan budaya tak benda Indonesia. Dari Propinsi Bengkulu ditetapkan menjadi warisan budaya Indonesia adalah budaya Kain Besurek, kain lantung, dan Umeak Potong Jang. Dan sekarang Kain Besurek lebih dikenal dengan nama Kain Batik Besurek. Di kota Bengkulu Kain Batik Besurek sangat mudah ditemukan dan dapat dibeli didaerah setra kerajinan Bengkulu dikawasan Anggut dengan harga kisaran mulai Rp.25.000/meter sampai jutaan/meternya . Selain itu Kain Batik Besurek sudah dijual dalam bentuk pakaian jadi seperti baju koko, kemeja, jilbab dan lain-lain bahkan juga dibuat dan dipadupadankan untuk barang lain seperti tas, topi, aksesoris dan lain sebagainya dengan harga yang sangat terjangkau dengan kualitas bahan yang baik.

\section{Analisis SWOT \\ Perhitungan SWOT \\ Faktor Internal (IFAS)}

Matrik IFAS digunakan untuk memperkenalkan dan memasarkan produk kain batik Besurek, maka harus membutuhkan strategi yaitu dengan membuat analisa yang meliputi kekuatan (Strength) dan Kelemahan (Weaknesess).

1. Kekuatan (Strength)

a. Memiliki motif yang khas dari motif batik Jawa, yaitu motif huruf Arab gundul yang di padukan dengan bunga Raflesia Arnoldi.

Untuk membedakan motif batik buatan Bengkulu dengan motif batik buatan Jawa maka dipatenkan motif yang khas berupa huruf arab gundul karena yang membawa pertamakali adalah Pangeran Sentot Ali Basya yang sekaligus menyiarkan agama Islam dan karena Bengkulu identik dengan Bunga Raflesia Arnoldi maka dipadukan agar masyarakat lebih cepat mengingat Bengkulu melalui batiknya.

b. Merupakan batik dari kawasan pulau Sumatra, yang mana biasanya orang hanya tahu batik Jawa saja.

Ada terobosan terbaru saat ini masyarakat sudah banyak yang mengenal batik bukan hanya berasal dari pulau Jawa tapi di pulau sumatera juga ada batik tidak kalah bagusnya dengan batik dari Jawa yaitu batik Besurek dari Bengkulu.

c. Kain Besurek sudah ditetapkan menjadi salah satu warisan budaya Indonesia dari Propinsi Bengkulu.

Sekarang ini masyarakat Bengkulu bole berbangga karena kain batik besurek merupakan salah satu warisan budaya Indonesia dari Propinsi Bengkulu yang mana hal ini berdasarkan dari hasil sidang penetapan warisan Budaya tak benda Indonesia tahun 2015 dilaksanakan pada tanggal 2023 September 2015 di Jakarta. Dalam sidang ini diputuskan sebanyak 121 karya budaya untuk ditetapkan sebagai warisan budaya tak benda Indonesia. Dari Propinsi Bengkulu ditetapkan menjadi warisan budaya Indonesia adalah budaya Kain Besurek, kain lantung, dan Umeak Potong Jang. Dan sekarang Kain Besurek lebih dikenal dengan nama Kain Batik Besurek.

d. Sudah dikenal oleh masyarakat Bengkulu

Di kota Bengkulu Kain Batik Besurek sudah sangat dikenal oleh masyarakat Bengkulu dan masyarakat bisa dengan mudah mendapatkan dan dapat dibeli didaerah setra kerajinan Bengkulu dikawasan Anggut dengan harga kisaran mulai Rp.25.000/meter sampai jutaan/meternya. Selain itu Kain Batik Besurek sudah dijual dalam bentuk pakaian jadi seperti baju koko, kemeja, jilbab dan lain-lain bahkan juga dibuat dan dipadupadankan untuk barang lain seperti tas, topi, aksesoris dan lain sebagainya dengan harga yang sangat terjangkau dengan kualitas bahan yang baik.

Setelah memperoleh bobot dan rating maka dapat diperoleh skor, dengan cara mengalikan bobot dengan rating, dapat dilihat pada tabel dibawah ini:

Tabel 1. Matrik Internal Factor analysis Summary "IFAS"

\begin{tabular}{|l|l|c|c|c|}
\hline No & \multicolumn{1}{|c|}{ KEKUATAN } & BOBOT & RATING & SKOR \\
\hline 1 & $\begin{array}{l}\text { Memiliki motif yang khas dari motif batik Jawa, yaitu motif huruf Arab } \\
\text { gundul yang di padukan dengan bunga Raflesia Arnoldi Paling tua di } \\
\text { Indonesia }\end{array}$ & 0,85 & 4 & 3,4 \\
\hline 2 & $\begin{array}{l}\text { Merupakan batik dari kawasan pulau Sumatra, yang mana biasanya } \\
\text { orang hanya tahu batik Jawa saja }\end{array}$ & 0,80 & 4 & 3,2 \\
\hline 3 & $\begin{array}{l}\text { Kain Besurek sudah ditetapkan menjadi salah satu warisan budaya } \\
\text { Indonesia dari Propinsi Bengkulu }\end{array}$ & 0,70 & 3 & 2,1 \\
\hline 4 & Sudah dikenal oleh masyarakat Bengkulu & 0,70 & 4 & 2,8 \\
\hline \multicolumn{1}{|c|}{ Jumlah } & $\mathbf{3 , 0 5}$ & $\mathbf{1 5}$ & $\mathbf{1 1 , 5}$ \\
\hline
\end{tabular}

Sumber : data diolah, 2017 
Dari hasil perhitungan diatas dapat diketahui bahwa pernyataan yang behubungan dengan kekuatan (strenghts) dapat disimpulkan bahwa keseluruhan pernyataan itu merupakan kekuatan bagi strategi pemasaran kain Batik Besurek

2. Kelemahan (Weaknesess)

a. Kalah pamor dari batik yang berasal dari Jawa

Batik di Indonesia begitu beragam. Setiap daerah memiliki batik dengan ciri khas tersendiri. Keunikan dan kekhasannya membuat siapapun takjub dan bangga memakainya. Karena Batik Nasional, tak dipungkiri lagi semua media menyorot dan menjadikan pembahasan utama tentang batik. Di salah satu acara di sebuah televisi swasta mengangkat tema batik. Dalam perbincangannya, disebutkan macam-macam batik dari berbagai daerah yang sering disebutkan, terkecuali, batik besurek khas Bengkulu.

b. Tidak mampu memproduksi dalam skala besar

Kendala yang paling besar dalam memproduksi kain besurek adalah belum mampu memproduksi dalam partai besar karena kurangnya bahan baku, modal dan peralatan yang belum mendukung.

c. Modal yang terbatas

Dalam memproduksi kain batik besurek pasti membutuhkan modal yang besar dalam memproduksi kain batik besurek yang berkwalitas . Pengusahan kain batik Besurek Bengkulu rata-rata tidak memiliki modal besar dalam memproduksi kain Besurek apalagi dalam partai besar.

d. Bahan baku yang masih di datangkan dari pulau Jawa, di karenakan harga bahan baku pulau Jawa lebih terjangkau.

Dalam memproduksi kain batik besurek pengraji membutuhkan bahan baku dalam memproduksi kain batik besurek. Untuk bahan baku didalam kota Bengkulu harga yang ditawarkan cukup tinggi dibanding kalau memesan dari pulau Jawa. Sehingga dapat menekan biaya produksi.

Setelah memperoleh bobot dan rating maka dapat diperoleh skor, dengan cara mengalikan bobot dengan rating,dapat dilihat pada tabel dibawah ini:

Tabel 2. Matrik Internal Factor analysis Summary "IFAS"

\begin{tabular}{|l|l|c|c|c|}
\hline No & \multicolumn{1}{|c|}{ KELEMAHAN } & BOBOT & RATING & SKOR \\
\hline 1 & Kalah pamor dari batik yang berasal dari Jawa & 0,80 & 4 & 3,2 \\
\hline 2 & Tidak mampu memproduksi dalam skala besar & 0,60 & 3 & 1,8 \\
\hline 3 & Modal yang terbatas & 0,40 & 4 & 1,6 \\
\hline 4 & $\begin{array}{l}\text { Bahan baku yang masih di datangkan dari } \\
\text { pulau Jawa, di karenakan harga bahan baku } \\
\text { pulau Jawa lebih terjangkau }\end{array}$ & 0,75 & 2 & 0,15 \\
\hline \multicolumn{1}{|c|}{ Jumlah } & $\mathbf{2 , 5 5}$ & $\mathbf{1 3}$ & $\mathbf{6 , 7 5}$ \\
\hline
\end{tabular}

Sumber : data diolah, 2017

\section{Faktor Eksternal (EFAS)}

Matrik EFAS digunakan untuk memperkenalkan dan memasarkan produk kain batik Besurek, maka harus membutuhkan strategi yaitu dengan membuat analisa yang Peluang (Opportunities) dan Ancaman (Threaths).

1. Peluang (Opportunities)

a. Batik Basurek masih dalam cakupan wilayah Bengkulu

Batik Besurek Bengkulu hanya terkenal di rumah sendiri dan mempunyai harapan untuk ekspansi lebih luas lagi sehingga dapat bersaing dengan batik yang berasal dari pulau Jawa.

b. Memiliki ciri khas motif yang unik dari kebanyakan batik Indonesia, yaitu motif huruf Arab gandul yang di padukan dengan bunga Raflesia.

Setiap batik pasti memiliki ciri khas motif tersendiri , tidak terkecuali batik besurek memiliki ciri khas yang sangat unik dan tidak ada yang sama motifnya dengan motif batik lainnya.

c. Mempunyai nilai sejarah yang tinggi sebagai benda seni tradisional Bengkulu.

Kalau dilihat dari sejarahnya kain batik Besurek memiliki nilai sejarah yang sangat tinggi karena kain batik besurek merupakan salah satu warisan budaya Indonesia dari Propinsi Bengkulu yang mana hal ini berdasarkan dari hasil sidang penetapan warisan Budaya tak benda Indonesia tahun 2015 dilaksanakan pada tanggal 20-23 September 2015 di Jakarta. Dalam sidang ini diputuskan sebanyak 121 karya budaya untuk ditetapkan sebagai warisan budaya tak benda Indonesia. 
d. Karakteristik masyarakat Bengkulu yang sulit menerima budaya luar Bengkulu.

Masyarakat Bengkulu memiliki karakter yang sangat sulit menerima budaya dari luar Bengkulu yang mengakibatkan lambatnya perkembangan budaya yang ada di Bengkulu contohnya adalah kain batik Besurek yang sebenarnya sudah ada sejak jaman dahulu tapi baru sekarang di ketahui oleh masyarakat luas.

Setelah memperoleh bobot dan rating maka dapat diperoleh skor, dengan cara mengalikan bobot dengan rating,dapat dilihat pada tabel dibawah ini :

Tabel 3. Matrik Enternal Factor analysis Summary "EFAS"

\begin{tabular}{|l|l|c|c|c|}
\hline No & \multicolumn{1}{|c|}{ PELUANG } & BOBOT & RATING & SKOR \\
\hline 1 & $\begin{array}{l}\text { Batik Basurek masih dalam cakupan wilayah } \\
\text { Bengkulu. }\end{array}$ & 0,75 & 4 & 3,0 \\
\hline 2 & $\begin{array}{l}\text { Memiliki ciri khas motif yang unik dari } \\
\text { kebanyakan batik Indonesia, yaitu motif huruf } \\
\text { Arab gandul yang di padukan dengan bunga } \\
\text { Raflesia }\end{array}$ & 0,80 & 4 & 3,2 \\
\hline 3 & $\begin{array}{l}\text { Mempunyai nilai sejarah yang tinggi sebagai } \\
\text { benda seni tradisional Bengkulu }\end{array}$ & 0,85 & 4 & 3,4 \\
\hline 4 & $\begin{array}{l}\text { Karakteristik masyarakat Bengkulu yang sulit } \\
\text { menerima budaya luar Bengkulu }\end{array}$ & 0,70 & 4 & 2,8 \\
\hline & \multicolumn{1}{|c|}{ Jumlah } & $\mathbf{3 , 1}$ & $\mathbf{1 6}$ & $\mathbf{1 2 , 4}$ \\
\hline
\end{tabular}

Sumber : data diolah, 2017

\section{Ancaman (Threaths)}

a. Pemasaran yang terbatas

Kendala yang paling berat adalah pemasaran kain batik Besurek yang hanya terbatas pada lingkungan masyarakat Bengkulu saja dan pemasaranny belum sampai ke luar daerah apalgi kemanca negara. Maka diharapkan adanya kerjasamma antara beberapa pihak yang terkait sehingga dapat memperluas pemasaran kain batik besurek tersebut .

b. Batik luar lebih laku terjual di bandingkan batik Basurek sendiri.

Tidak dapat dipungkiri lagi masyarakat lebih senang membeli batik yang berasal dari pulau jawa dibanding batik Besurek dari daerahnya sendiri. Ini disebabkan karena batik dari pulau Jawa selain harganya murah, batik dari pulau Jawa mudah didapat .

c. Kurang kerjasama kemitraan dengan pihak terkait.

Kerjasama kemitran sebaiknya dijalin oleh pemerintah kota Bengkulu. Misalnya memberikan brosur-brosur dan pajangan kain batik Besurek dimaskapai penerbangan , diperhotelan dan agen traveling dalam dan luar kota. Menjalin kemitraan dengan pengusaha ataupun dengan pihak investor akan memberikan manfaat untuk mengembangkan kain batik Besurek kedepannya.

d. Kurangnya dukungan pemerintah dalam meningkatkan SDM serta Pemasaran kain batik Besurek.

Sumber Daya Manusia yang kurang terampil membuat perkembangan dari kain batik Besurek menjadi lamban karena kurang adanya dukungan dari pemerintah untuk mengembangkan SDM apalagi memberikan pelatihan-pelatihan kepada pengrajin kain batik Besurek .

Setelah memperoleh bobot dan rating maka dapat diperoleh skor, dengan cara mengalikan bobot dengan rating,dapat dilihat pada tabel dibawah ini :

Tabel 4. Matrik Enternal Factor analysis Summary "EFAS"

\begin{tabular}{|l|l|c|c|c|}
\hline No & \multicolumn{1}{|c|}{ ANCAMAN } & BOBOT & RATING & SKOR \\
\hline 1 & Pemasaran yang terbatas & 0,70 & 4 & 2,8 \\
\hline 2 & $\begin{array}{l}\text { Batik luar lebih laku terjual di bandingkan batik } \\
\text { Basurek sendiri }\end{array}$ & 0,73 & 4 & 2,92 \\
\hline 3 & Kurang kerjasama kemitraan dengan pihak terkait & 0,85 & 3 & 2,55 \\
\hline 4 & $\begin{array}{l}\text { Kurangnya dukungan pemerintah dalam meningkatkan } \\
\text { SDM serta Pemasaran kain batik Besurek }\end{array}$ & 0,65 & 4 & 2,6 \\
\hline & \multicolumn{1}{|c|}{ Jumlah } & $\mathbf{2 , 9 3}$ & $\mathbf{1 5}$ & $\mathbf{1 0 , 8 7}$ \\
\hline
\end{tabular}




\section{Diagram Analisis SWOT}

Dari analisis SWOT diatas maka dapat dibuat suatu ringkasan atau rekapitulasi dari perhitungan untuk melihat seberapa besar kekuatan, kelemahan, peluang, dan ancaman yang terjadi pada strategi pemasaran kain batik Besurek.

Tabel 5. Rekapitulasi IFAS dan EFAS

\begin{tabular}{|l|c|c|c|c|}
\hline Keterangan & \multicolumn{2}{|c|}{ IFAS } & \multicolumn{2}{c|}{ EFAS } \\
\hline & Strengths & Weaknesses & Opportunities & Threats \\
\hline Strategi pemasaran & 11,5 & 6,75 & 12,4 & 10,87 \\
\hline Kuadran & \multicolumn{2}{|c|}{$11,5-6,75=4,75$} & $12,4-10,87=1,57$ \\
\hline
\end{tabular}

Sumber : data diolah 2017.

Diagram Cartesius Analisis SWOT akan menujukan pada posisi manakah strategi pemasaran kain batik besurek Bengkulu saat ini . Posisi strategi inilah yang akan menentukan letak kuadran strategi pemasaran. Kuadran tersebut akan menjadi fundamental analisis strategi kedepan, kuadran- kuadran dapat diamanti secara jelas melalui diagram Cartesius Analisis SWOT berikut ini:

Gambar 2. Diagram Cartesius Analisis SWOT Strategi Pemasaran kain Batik Besurek di Kota Bengkulu.

\begin{tabular}{|c|c|c|c|}
\hline & \multicolumn{2}{|c|}{$\begin{array}{c}\text { Peluang (Opportunity) } \\
12,4 \\
\end{array}$} & \\
\hline $\begin{array}{l}\text { Kuadran } 3 \\
\text { Mendukung Strategi } \\
\text { Turn around }\end{array}$ & \multirow[t]{2}{*}{4,75} & \multicolumn{2}{|c|}{$\begin{array}{l}\text { kuadran } 1 \\
\text { Mendukung strategi } \\
\text { agresif (Growth) }\end{array}$} \\
\hline $\begin{array}{c}\text { Kelemahan (Weakness) } \\
6,75\end{array}$ & & & Kekuatan (Strength) 11,5 \\
\hline \multirow[t]{2}{*}{$\begin{array}{l}\text { Kuadran } 4 \\
\text { Mendukung Strategi } \\
\text { Defensiv }\end{array}$} & \multicolumn{3}{|c|}{$\begin{array}{l}\text { kuadran } 2 \\
\text { Mendukung strategi } \\
\text { diversifikasi }\end{array}$} \\
\hline & \multicolumn{3}{|c|}{ Ancaman (Threath) 10,87 } \\
\hline
\end{tabular}

Sumber : data diolah, 2017

Dari nilai masing-masing faktor maka dapat digambarkan juga SWOT dalam rumusan SWOT seperti tabel dibawah ini :

Tabel 6. Rumusan kombinasi strategi materik SWOT

\begin{tabular}{|c|c|c|}
\hline EFAS IFAS & $\begin{array}{l}\text { Kekuatan } \\
\text { Strengths }(S)\end{array}$ & $\begin{array}{l}\text { Kelemahan } \\
\text { Weakness }(W)\end{array}$ \\
\hline $\begin{array}{l}\text { Peluang } \\
\text { Oppourtunity }(\mathrm{O})\end{array}$ & $\begin{array}{l}\text { Strategi SO: } \\
=11,5+12,4 \\
=23,9\end{array}$ & $\begin{array}{l}\text { Strategi WO: } \\
=6,75+12,4 \\
=19,15\end{array}$ \\
\hline $\begin{array}{l}\text { Ancaman } \\
\text { Threats }(T)\end{array}$ & $\begin{array}{l}\text { Strategi ST: } \\
=11,5+10,87 \\
=22,37\end{array}$ & $\begin{array}{l}\text { Strategi } W T \text { : } \\
=6,75+10,87 \\
=17,62\end{array}$ \\
\hline
\end{tabular}

Sumber ; data diolah,2017

Berdasarkan diagram diatas maka titik berada pada kuadran I yaitu merupakan situasi yang sangat menguntungkan. Kain batik Besurek di kota Bengkulu memiliki peluang dan kekuatan yang besar 
sehingga dapat memanfaatkan peluang yang ada. Strategi yang diterapkan dalam kondisi ini adalah mendukung kebijakan yang agresif. Adapun alternatif strategi intergrasi yang dapat dipakai yaitu dengan cara :

1. Melakukan Strategi integrasi konsentrik, dengan cara Pengembangan Pasar, hal ini dilakukan dengan perencanaan yang matang dan memerlukan promosi yang jauh lebih agresif didukung oleh strategi harga yang terjangkau.

2. Melakukan intergrasi horizontal, dengan cara Peningkatan kemampuan SDM, dengan cara pemberian Peningkatan keterampilan SDM pengerajin penjahit, pelatihan manajemen, ekspor dan tata kelola ruang produksi, belajar membuat 40 desain motif batik besurek, belajar mendesain 40-60 desain busana serta pelatihan pemasaran secara online

3. Melakukan strategi Pengembangan Produk dengan cara belajar membuat Tas, sepatu, sandal, dompet dan lainnya dengan menggunakan kain batik Besurek.

Sedangkan bila melihat rumusan Matrik SWOT pada tabel 5.15 selanjutnya dilakukan analisis kualitatif perumusan strategi. Pembuatan analisis model kuantitatif tersebut didasari pada jumlah nilai skor pada masing-masing faktor yang ada pada masing-masing strategi baik itu SO,WO,ST dan WT maka dapat digambarkan model kuantitatif rumusan strategi pada tabel 5.15.

Dari tabel 5.15 matrik perencanaan kombinasi strategi kuantitatif menunjukan bahwa pemasaran kain batik Besurek perlu memanfaatkan Strategi SO yang mempunyai nilai tertinggi sebesar 23,9 selanjutnya diikuti strategi $\mathrm{ST}=22,37, \mathrm{WO}=19,15$ dan $\mathrm{WT}=17,62$. Adapun masing-masing strategi yaitu meningkatkan kualitas SDM baik untuk pengrajin maupun pengusahannya, mengoptimalkan kualitas barang dan harga agar dapat bersaing dengan batik yang lain . Melakukan Pengadaan dan perbaikan peralatan penunjang. Melakukan perencanaan yang matang dan memerlukan promosi yang jauh lebih agresif. Adapun matrik perencanaan strategi kuantitatif dapat dilihat dilihat dalam tabel dibawah ini:

Tabel 7. Matrik Perencanaan Kombinasi perencanaan strategi kuantitatif

\begin{tabular}{|c|c|c|}
\hline $\begin{array}{ll}\text { EFAS } & \text { IFAS } \\
\end{array}$ & $\begin{array}{c}\text { Kekuatan Strengths } \\
(\mathrm{S}) \\
\end{array}$ & $\begin{array}{c}\text { Kelemahan Weakness } \\
(\mathrm{W}) \\
\end{array}$ \\
\hline $\begin{array}{l}\text { Peluang } \\
\text { Opportunity (O) }\end{array}$ & $\begin{array}{l}\text { Strategi SO : } \\
\text { Menggunakan kekuatan untuk } \\
\text { memanfaatkan peluang }=23,9\end{array}$ & $\begin{array}{l}\text { Strategi WO : } \\
\text { Meminimkan Kelemahan untuk } \\
\text { memanfaatkan peluang }=19,15\end{array}$ \\
\hline $\begin{array}{l}\text { Ancaman } \\
\text { Threats (T) }\end{array}$ & $\begin{array}{l}\text { Strategi ST: } \\
\text { Menggunakan kekuatan untuk mengatasi } \\
\text { ancaman }=22,37\end{array}$ & $\begin{array}{l}\text { Strategi WT : } \\
\text { Meminimkan kelemahan untuk } \\
\text { menghindari ancaman }=17,62\end{array}$ \\
\hline
\end{tabular}

Sumber : data diolah,2017

\section{Menganalisis dan Menentukan Keputusan Strategi dengan menggunakan Matrik SWOT.}

Dalam menyusun strategi pemasaran perusahaan harus menggunakan alat tertentu . Menurut Rangkuti (2006:31), matrik SWOT adalah alat yang dipakai untuk menyusun faktor-faktor strategi perusahaan. Matrik SWOT ini digambarkan bagaimana manajemen dapat dicocokkan peluang-peluang dan ancaman-ancaman eksternal yang dihadapi suatu perusahaan tertentu dengan kekuatan dan kelemahan internalnya, untuk menghasilkan empat rangkaian alternatif strategi (hunger dan Wheelen, 2004:232). berikut:

Matrik ini dapat menghasilkan empat set kemungkinan alternatif strategi dapat dilihat pada tabel 
Tabel 8. Matrik SWOT

\begin{tabular}{|c|c|c|}
\hline EFAS & 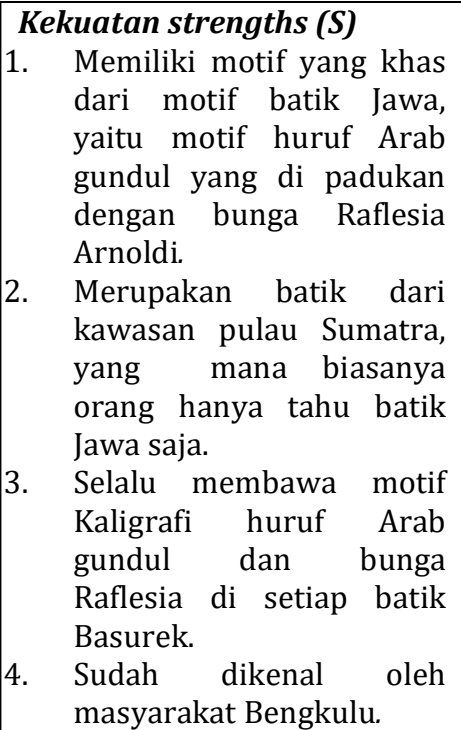 & $\begin{array}{l}\text { KelemahanWeakness }(\boldsymbol{W}) \\
\text { 1. Kalah pamor dari batik yang } \\
\text { berasal dari Jawa. } \\
\text { 2. Tidak mampu memproduksi } \\
\text { dalam skala besar. } \\
\text { 3. Sejarah tentang batik } \\
\text { Basurek yang kurang. } \\
\text { 4. Bahan baku yang masih di } \\
\text { datangkan dari pulau } \\
\text { Jawa, di karenakan harga } \\
\text { bahan baku pulau Jawa } \\
\text { lebih terjangkau }\end{array}$ \\
\hline $\begin{array}{l}\text { Peluang Opportunity (O) } \\
\text { 1. Batik Besurek masih dalam } \\
\text { cakupan wilayah Bengkulu. } \\
\text { 2. Memiliki ciri khas motif yang } \\
\text { unik dari kebanyakan batik } \\
\text { Indonesia, yaitu motif huruf Arab } \\
\text { gandul yang di padukan dengan } \\
\text { bunga Raflesia. } \\
\text { 3. Mempunyai nilai sejarah yang } \\
\text { tinggi sebagai benda seni } \\
\text { tradisional Bengkulu. } \\
\text { 4. Karakteristik masyarakat Bengkulu } \\
\text { yang sulit menerima budaya luar } \\
\text { Bengkulu }\end{array}$ & $\begin{array}{l}\text { Strategi SO } \\
\text { 1. Perluasan pangsa pasar } \\
\text { 2. promosi yang jauh lebih } \\
\text { agresif } \\
\text { 3. Meningkatkan kualitas } \\
\text { SDM. } \\
\text { 4. Memelihara kualitas serta } \\
\text { mutu produk. }\end{array}$ & $\begin{array}{l}\text { Strategi WO } \\
\text { 1. } \begin{array}{l}\text { Meningkatkan } \\
\text { produk. }\end{array} \\
\text { 2. } \begin{array}{l}\text { Mengusahakan } \\
\text { pengembangan } \\
\text { pelatihan SDM. } \\
\text {. }\end{array}\end{array}$ \\
\hline $\begin{array}{l}\text { Ancaman Threats (T) } \\
\text { 1. Kurang adanya loyalitas dan } \\
\text { kebanggaan masyarakat } \\
\text { Bengkulu terhadap batik Besurek. } \\
\text { 2. Batik luar lebih laku terjual di } \\
\text { bandingkan batik Besurek sendiri. } \\
\text { 3. Pesatnya penjualan batik yang } \\
\text { berasal dari pulau Jawa. } \\
\text { 4. } \\
\text { Masyarakat hanya cenderung } \\
\text { mengenal jenis motif batik Jawa } \\
\text { yang sudah terkenal sejak dulu }\end{array}$ & $\begin{array}{l}\text { Strategi ST } \\
\text { 1. Melakukan Pengembangan } \\
\text { Produk. } \\
\text { 2. Meningkatan kualitas dan } \\
\text { mutu produk maupun } \\
\text { pelayanan. } \\
\text { 3. } \begin{array}{l}\text { Menetapkan } \\
\text { harga. }\end{array}\end{array}$ & 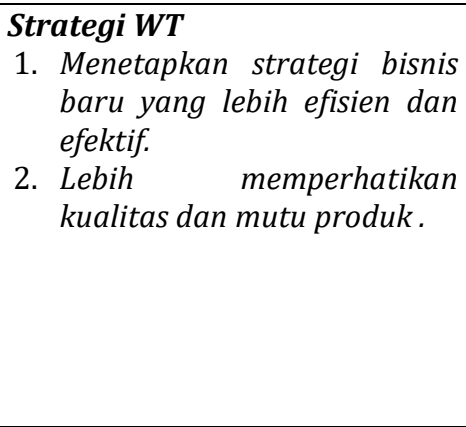 \\
\hline
\end{tabular}

Sumber : data diolah,2017

\section{KESIMPULAN}

1. Berdasarkan data didapat bahwa titik pertemuan antara kekuatan, kelemahan, peluang dan ancaman berada pada kuadran I .Pada kuadran I ini berarti merupakan situasi yang sangat menguntungkan. Perusahaan tersebut memiliki peluang dan kekuatan sehingga dapat memanfaatkan peluang yang ada. Strategi yang diterapkan dalam kondisi ini adalah mendukung kebijakan yang agresif.

2. Berdasarkan Diagram Cartesius Analisis SWOT "Pemasaran kain batik Besurek di Kota Bengkulu" berada pada kuadran I yaitu dengan cara strategi integrasi, sehingga strategi pemasaran tersebut adalah :

a. Melakukan Strategi integrasi konsentrik

b. Melakukan intergrasi horizontal

c. Melakukan strategi Pengembangan Produk 


\section{SARAN}

1. Para produsen batik besurek dikota Bengkulu diharapkan untuk dapat lebih inovatif dan lebih mengikuti selera masyarakat, agar permintaan produk lokal batik besurek dikota Bengkulu terus meningkat dan berkembang.

2. Melakukan promosi yang lebih agresif dan mengelar festival batik Besurek agar masyarakat dapat mengetahui informasi mengenai kain batik Besurek yang ada di Bengkulu.

\section{DAFTAR PUSTAKA}

Asti musman dan Arini.B Ambar . 2011.Warisan Adiluhung Nusantara ,Yogyakarta ANDI.

Anonym. 2009. Analisis SWOT: Tehnik membedah kasus Bisnis, Jakarta, Erlangga

Assuri, Sofjan. 2010. Manajemen Pemasaran.Edisi Sepuluh, Jakarta, Persada

Basu Swasta D dan T. Hani Handoko 2000 Manajemen PemasaranAnalisis Prilaku Konsumen, Edisi Pertama .BPEE.

Daryanto. 2013. Manajemen Pemasaran. Bandung PT. Sarana Tutorial Nurani Sejahtera Bandung.

Fahmi, Irham.2013. Manajemen Risiko : Teori, kasus, dan solusi. Bandung, Alpabeta

Freddy Firmansyah Marpaung. 2016. Strategi Pemasaran pada PT. Indomarco Adi Prima Point gading Cempaka non pasar (SP.GNP) Bengkulu Volume 4. No.1 Bulan Januari 2016 ISSN : 2338-8412

http://ardli099.mywapblog.com/sejarah-dan-asal-usul-kain-besurek.xhtml

Herry Lisbijanto. 2013 Batik Edisi Pertama Graha Ilmu ,Yogyakarta.

Mursid,M.2008. Manajemen Pemasaran,Jakarta . Bumi Aksara.

Prawirosentono, Suryadi. 2009. Manajemen Operasi, Analisis dan Study Kasus. Edisi Keempat . Jakarta .Bumi Aksara.

Rangkuti, Freddy. 2006 . Analisis SWOT Tehnik Membedah Kasus Bisnis. Cetakan ke Dua Belas. Jakarta . Gramedia Pustaka Utama.

Stanton, William.J. 2013. Manajemen Pemasaran. Bandung PT. Sarana Tutorial Nurani Sejahtera Bandung.

Sugiyono, 2010, Metode Penelitian Kuantitatif kualitatif dan R dan D,Bandung, Alfabet 